\title{
RETURNS OF ASSETS IN CORRUPTION CRIMINAL ACTS AS ALTERNATIVE RESTORING STATE LOSSES
}

\author{
Komang Ekayana \\ Universitas Pendidikan Ganesha \\ Email: komangekayana@yahoo.com
}

\begin{abstract}
Abstrak
Corrupted state assets certainly hurt the country narrowly, but also broadly where it harms the country and its people. However, the formal approach through the current criminal procedure law has not been able to recover the losses suffered by the state. In fact, state losses resulting from corruption are state assets that must be saved. Then there needs to be a new breakthrough to recover state losses through the asset recovery model. When looking at the country from the perspective of the victims, the state must obtain protection, in this case recovery from the losses suffered due to corruption. This paper examines the model of returning assets resulting from corruption in the law enforcement process that focuses on the rule of law in the 2003 UNCAC Convention and the mechanism of returning state assets in terms of Law No. 20 of 2001 concerning amendments to Law No. 31 of 1999 concerning Eradication of Corruption Crimes.
\end{abstract}

Keywords: asset recovery, assets, corruption, state losses.

\section{Background}

One of the most criminal cases which caught the attention of the Indonesian people in recent years is the corruption case. Where, this case involves a variety of professional backgrounds, both judges, prosecutors, police, members of the council, governors, mayors, regents, to businessmen.

Corruption is a criminal act that directly or indirectly harms the country's finances or economy, and has implications for the people. So that it can be said that the victims of corruption are the state and the people, because with corruption there is economic instability that has a wide impact on the development and welfare of the people. ${ }^{1}$

The corrupted state assets not only narrowly affect the state, but also

\footnotetext{
${ }^{1}$ Artidjo Alkostar, Kerugian Keuangan Negara dalam Perspektif Tindak Pidana Korupsi, Varia Peradilan No. 275 Oktober 2008, hlm 34-35.
}

broadly where it harms the country and its people. Some corruptors who are sentenced to fines, then prefer to be replaced with imprisonment. this means a barrier to recovering state losses. From this problem, in recent years the idea has been to impoverish corruptors by confiscating assets of corruption. However, the formal approach through the current criminal procedure law has not been able to recover the losses suffered by the state. In fact, state losses resulting from corruption are state assets that must be saved. Then there is a need for a new breakthrough to recover state losses through an asset recovery model that is experienced by the state outside of the principal crime in order to maximize the additional crimes prosecuted against the corruptors.

Law enforcement and restoration of state assets due to crime are two sides of a coin that cannot be separated in eradicating criminal acts, especially 
corruption. Crimes are based on thought calculations or calculations, then management and security are the main focus for corruptors. Someone dares to commit corruption if the outcome of corruption is higher than the risk of punishment faced, even they are ready to go to jail if he estimates that while serving his sentence, his family can still prosper.

So that the eradication of corruption is not enough to punish the perpetrators, but must be balanced with efforts to cut the flow of funds resulting from crime. By confiscating and seizing assets resulting from corruption. So it is expected that someone loses motivation to commit corruption because his goals are blocked by existing regulations.

Therefore, the purpose of this paper is to examine the application of an asset recovery model as an alternative to law enforcement in cases of corruption under the UNCAC Convention 2003. and examine the application of an asset recovery model in an effort to recover state losses through criminal channels based on the Law No. 20 of 2001 concerning Amendment to Law No. 31 of 1999 concerning Eradication of Corruption Crimes.

The formulation of the problems that can be submitted in this paper based on the background above, as follows:

1. What is the mechanism for asset recovery in corruption cases based on the 2003 UNCAC Convention?

2. What is the mechanism for recovering state losses through criminal channels?

\section{Research Methods}

This writing uses normative legal research methods with descriptive type

${ }^{2}$. This writing uses a juridical approach 2 Deskritif dimaksudkan untuk memberikan
gambaran tentang obyek yang akan di bahas. and secondary data sources, ${ }^{3}$ and uses qualitative data analysis with content analysis techniques. ${ }^{4}$

\section{Discussion}

Asset recovery (asset recovery) tends polelemic in handling. The vague mechanism and implementation of the legal system apparently triggered the difficulty of returning state assets. It cannot be denied that the current law enforcement, corruptors tend to only be sentenced to prison. Even though the recovery of assets carried out by law enforcement officials is still not comparable to the losses suffered by the state.

To understand what state losses are like so that an action can be said to have harmed state assets through corruption is a loss caused to the country's finances or the country's economy. Based on Article 1 paragraph (22) of Law No. 1 of 2004 concerning the State treasury, the definition of state or regional financial losses is "lack of real, definite and definite amounts of money, securities and goods as a result of intentional or negligent unlawful acts". Based on this understanding, three elements regarding state losses are found, as follows: ${ }^{6}$

a) State loss is the reduction in state finances in the form of valuable money,

\footnotetext{
3 Analisis dikaitkan dengan teori-teori hukum yang ada dan/atau peraturan peraturan perundang-undangan yang berkaitan dengan obyek penelitian.

4 Soerjono Soekanto dan Sri Mamudji, Penelitian Hukum Normatif: Suatu Tinjauan Singkat, (Jakarta: Raja Grafindo Persada, 2003), Hlm 12.

${ }^{5}$ Pasal 1 ayat (22) Undang-undang No. 1 Tahun 2004 tentang pembendaharaan Negara.

6 Guntur Rambey, Pengembalian Kerugian Negara dalam Tindak Pidana Korupsi Melalui Pembayaran Uang Pengganti dan Denda, De Lega Lata, Vol. 1, N0. 1, Januari-Juni 2016, hlm 148.
} 
state-owned goods from the amount and / or the proper value.

b) Deficiencies in the country's finances must be real and definite the amount in other words the losses have actually occurred with the amount of losses that can be determined with certainty. So that the state loss is only an indication or in the form of a potential loss.

c) The loss is due to acts against the law, whether intentionally or negligently, the element of violating the law must be proven carefully

In general explanation of Law No. 31 of 1999 states that state finances are all state assets in any form, separated or not separated, including all parts of state assets and all rights and obligations arising from: (a) being in the possession, management and accountability of agency officials the state both at the central and regional levels; and (b) is in control, management and accountability of State-Owned Enterprises / RegionalOwned Enterprises, foundations, legal entities, and companies that include state capital, or companies that include third party capital based on an agreement with the state, whereas what is meant by the economy the state is economic life compiled as a joint venture based on the principle of family and community business independently based on government policies, both at the central and regional levels in accordance with the provisions of the applicable laws and regulations aimed at providing benefits, prosperity, and welfare to all people's lives.

Based on the provisions of Article 1 paragraph (22) of Law no. 1 of 2004 as stated above, it can be seen that the concept adopted is the concept of state losses in the sense of material offense in which actions or actions can be said to be detrimental to state finances on condition that state losses must be truly evident, whereas in Article 2 paragraph (1) of Law No. 31 of 1999 explained that state losses in the concept of formal offenses are said to be detrimental to the country's finances or the country's economy.

From some of the provisions above, it can be said that the concept of state losses in the sense of material offense can no longer be used or can no longer be maintained because an action can be said to be corruption or that preparatory actions must be taken but not yet real to the detriment of state finances. These preparatory actions will also lead to acts that can harm the country's finances so as to prevent a corrupt act that actually harms the country's finances it is advisable to use the formal offense concept in determining whether or not state financial losses have occurred. ${ }^{7}$

1. Asset Recovery as an Effort to Recover State Losses The essence of corruption eradication can be divided into three important things, namely through preventive actions, repressive actions, and restorative measures. Preventive action is related to the existence of regulations concerning the eradication of corruption in the hope of preventing the public from committing corruption. Reproductive action is related to the active implementation of law enforcement carried out by the authorities in the event of a criminal act of corruption. As well as restorative measures in this case one of which is the return of assets of perpetrators of corruption through adequate criminal acts and / or civil law

In the modern era with a globalization system where efforts to restore or

\footnotetext{
${ }^{7}$ Ibid., hlm 149.
} 
recover stolen asset recovery through corruption are very difficult. The corruptors (perpetrators of criminal acts of corruption) have very broad access so that it is difficult to reach with regard to the assets they hide and to launder money resulting from criminal acts of corruption which usually leads to crossing national borders. In response to this fact the Indonesian State has a great opportunity to recover state assets as a result of corruption, because Indonesia has ratified UNCAC 2003 into its national law.

The United Nations Convention Against Corruption (UNCAC) governs asset recovery in Chapter $\mathrm{V}$, returning these assets is a basic principle in UNCAC 2003. Where each country must provide assistance and participating countries must provide mutual cooperation and assistance the widest on this matter. The Government of Indonesia has ratified the 2003 UNCAC based on Law No. 7 of 2006 concerning Ratification of UNCAC 2003, State Gazette (LN) No. 32 of 2006, Supplement to the State Gazette (TLN) No. 4620, in accordance with Law No. 24 of 2000 concerning International Treaties. The act of ratification is carried out through a law approved by the House of Representatives of the Republic of Indonesia which has adopted the Convention as Indonesian National Law which creates legal obligations for each institution or individual in Indonesia. ${ }^{8}$

The objectives of UNCAC are contained in Chapter I Article 1 which states: first, to increase and strengthen actions to prevent and eradicate corruption more efficiently and effectively; second, to enhance, facilitate and support international

\footnotetext{
8 Jamin Ginting, Perjanjian Internasional dalam Pengembalian Aset Hasil Korupsi di Indonesia, Jurnal Dinamika Hukum Vol. 11 No. 3 September 2011, hlm 452-453.
}

cooperation and technical assistance in efforts to prevent and eradicate corruption, including the return of assets, and to bind integrity, accountability and management of problems and public wealth properly and correctly. These goals form the roots of reformation in tackling the problem of transnational corruption. Adhering to the principle of mutual respect for each of the parties to the convention then an agreement was reached to use UNCAC as a legal basis for cracking down on corruptors.

The components contained in the UNCAC article have led to broader developments regarding the need for technical assistance to assist in the anticorruption agenda recognized by all countries. In this case involving developing countries and developed countries. These needs are accommodated and fulfilled in accordance with the contents contained in UNCAC. The state here remains the main focus in combating criminal acts of corruption because it is the state that has full sovereignty (state sovereignty) so that it has power over the things that happen on it. Participating countries and the ratification of the Convention have fully understood and agreed to use legal means to recover corrupt assets as part of the collective responsibility of all countries, not only countries whose assets or assets are corrupt. Cooperation between countries is important because corruption is no longer a local or national crime. Corruption has become an extraordinary crime (extra ordinary crime) that is transnational or across national borders. ${ }^{9}$ There are three attempts to recover foreign assets

\footnotetext{
9 Teuku Herizal, dkk. Analisis Yuridis Pengembalian Aset Hasil Korupsi Melalui Gugatan Perdata Terhadap Ahli Waris. Jurnal Ilmu Hukum Pascasarjana Universitas Syiah Kuala, Vol. 2, No. 2, (Agustus 2014): 51.
} 
through UNCAC. First, by prosecuting corruptors through civil law (civil allegation). Intended to freeze stateowned assets so that they can be frozen in the local country of the assets stored. Also, to prevent these assets from running away, the government will conduct full disclosure so that they cannot be touched again by corruptors. Second, the government through UNCAC can carry out forced seizures of physical assets owned by corruptors. Third, using the UNCAC's power in countries suspected of being corrupt hiding places. ${ }^{10}$

There are two important instruments to support UNCAC, namely, first, Mutual Legal Assistant (MLA), which is a means or a forum for requesting assistance from other countries to conduct investigations, prosecutions, and examinations of cases involving two or more countries. . The Indonesian government already has a law as paying from MLA, which is Law No. 1 of 2006 concerning the Reciprocal Assistance Agreement in effect since 3 March 2006. Besides that, it is also contained in Law No. 8 of 2010 concerning Eradication of Money Laundering Criminal Acts, stated in Article 88 to Article 91 concerning MLA and other cooperation in the context of tracing assets and returning assets as a crime of money laundering. Regarding MLA, it is also stipulated in UNCAC in Article 46. Second, extradition, this term is usually used mainly in the transfer of perpetrators of crimes from one country to the requesting country. The return of corruptors to their home countries can also be done with an extradition agreement.

${ }^{10}$ Ginting, op.cit., hlm 453-454.

\section{Return of State Assets Through the Criminal Path}

In the case of returning assets by the AGO and the second KPK based on Law Number 20 of 2001 concerning Amendment to Law Number 31 of 1999 concerning Eradication of Corruption. In addition to the two laws, Law Number 16 of 2004 concerning the Attorney General's Office of the Republic of Indonesia and Law Number 30 of 2002 concerning the Corruption Eradication Commission are the legal bases used in accordance with their respective agencies.

The mechanism of returning assets in Article 18 paragraph (1) letter a of Law Number 31 of 1999 in conjunction with Law Number 20 of 2001 reads as follows:

"Confiscation of tangible or intangible immovable property or immovable property used for or obtained from a criminal act of corruption, including convicted companies where a criminal act of corruption is committed, as well as the price of the goods that replace these items".

Furthermore, in Article 18 paragraph (1) letter b of Law Number 31 of 1999 in conjunction with Law Number 20 of 2001 as follows:

"Payment of replacement money as much as is equal to assets obtained from criminal acts of corruption"

While in Article 38 paragraph (5), (6), (7) of Law Number 31 of 1999 in conjunction with Law Number 20 of 2001 as follows:

"(5) in the event that the defendant dies before the verdict is handed down and there is sufficient strong evidence that the person concerned has committed a criminal act of corruption, then the judge on the demands of the public prosecutor determine the confiscation of confiscated items. (6). appropriation as intended in paragraph (5) cannot be 
appealed for appeal. (7). everyone who has an interest can submit an objection to the court that has dropped the stipulation as referred to in paragraph (5), within 30 (thirty) days from the date of the announcement as referred to in paragraph (3). "

\section{Conclusions}

Returning assets as an effort to recover state losses through criminal channels is very necessary to be done by the Indonesian Government. Various methods must be taken to strive to eradicate corruption that has mushroomed in Indonesia. Armed with existing legislation must be maximized. The Indonesian government must memorize the ratified UNCAC plus Law no. 20 of 2001 amendments to Law No. 31 of 1999 concerning Eradication of Corruption and Law No. 8 of 2010 concerning Money Laundering Crimes. Make existing laws and regulations to maximize the recovery of state assets stolen by corruptors.

The Government of Indonesia which has ratified the 2003 UNCAC based on Law No. 1 of 2006, is still unable to fully implement the principles contained in the 2003 UNCAC, including the absence of a non conviction base in criminal law, the absence of the establishment of a special institution to manage and administer assets originating from criminal acts including acts criminal corruption as a guarantor for recovered assets.

Lack of government to focus on increasing international cooperation to strengthen MLA and extradition agreements to make it easier to process criminal offenses, especially transnational corruption.

The incomplete regulations suggested in UNCAC 2003 show that the
Government of Indonesia has not consistently implemented the recommendations expected by UNCAC 2003 and this will have an effect on corruption that occurs in the national sphere, especially across national borders.

The mechanism of returning state assets through criminal channels in terms of regulations and legal theory is very good but in its implementation it is still lacking in the recovery of stolen state assets. The mechanism of confiscation of goods resulting from criminal acts of corruption from the perpetrators of corruption, then the court's decision must have permanent legal force. The law on corruption eradication still maintains this type of additional criminal offenses, because an additional criminal offense may be imposed in the form of payment of compensation in the amount of as much as the assets obtained from the criminal act of corruption. The execution of the substitute criminal payment decision is carried out by the Prosecutor's Office as an execution apparatus

\section{Suggestion}

The suggestions that can be delivered are, as follows:

a) The government should complete the regulation or update the existing regulations by passing the new corruption act law by absorbing UNCAC 2003, especially the part of returning state assets.

b) As for some of the Indonesian legal rules that need to be adapted to UNCAC 2003 are:

a. Asset return through non conviction base

b. Making legal instruments in the Criminal Procedure Code especially inverted proof.

c. Criminalization of bribery in the private sector. 
c) The government should have been more aggressive in entering into international agreements through MLA and extradition agreements in order to make the return of state assets across borders more effective.

\section{References}

Ariani, N. M. I., Yuliartini, N. P. R., \& Mangku, D. G. S. (2020). Implementasi Undang-Undang Nomor 11 Tahun 2012 tentang Sistem Peradilan Pidana Anak Terhadap Curanmor yang dilakukan Oleh Anak di Kabupaten Buleleng (Studi Kasus Perkara Nomor: B/346/2016/Reskrim). Jurnal Komunitas Yustisia, 2(2), 71-80.

Artidjo Alkostar, Kerugian Keuangan Negara dalam Perspektif Tindak Pidana Korupsi, Varia Peradilan No. 275 Oktober 2008, hlm 3435.

Dwiyanti, K. B. R., Yuliartini, N. P. R., SH, M., Mangku, D. G. S., \& SH, L. M. (2019). Sanksi Pidana Penyalahgunaan Narkotika Dalam Undang-Undang No. 35 Tahun 2009 Tentang Narkotika (Studi Putusan Penyalahgunaan Narkotika Golongan I Oleh Anggota Tni Atas Nama Pratu Ari Risky Utama). Jurnal Komunitas Yustisia, 2(1).

Guntur Rambey, Pengembalian Kerugian Negara dalam Tindak Pidana Korupsi Melalui Pembayaran Uang Pengganti dan Denda, De Lega Lata, Vol. 1, N0. 1, Januari-Juni 2016, hlm 148.

Herizal, Teuku, dkk. Analisis Yuridis Pengembalian Aset Hasil Korupsi Melalui Gugatan Perdata Terhadap Ahli Waris. Jurnal Ilmu Hukum Pascasarjana Universitas Syiah Kuala, Vol. 2, No. 2, (Agustus 2014): 51.
Himawan Ahmed Sanusi, Mekanisme Pengembalian Aset Hasil Tindak Pidana Korupsi, hlm 3-5.

Jamin Ginting, Perjanjian Internasional dalam Pengembalian Aset Hasil Korupsi di Indonesia, Jurnal Dinamika Hukum Vol. 11 No. 3 September 2011, hlm 452-453.

Kitab Undang-Undang Hukum Acara Pidana.

Kitab Undang-Undang Hukum Pidana. Putra, A. S., Yuliartini, N. P. R., SH, M., Mangku, D. G. S., \& SH, L. M. (2019). Sistem Pembinaan Terhadap Narapida Narkotika Di Lembaga Pemasyarakatan Kelas IIB Singaraja. Jurnal Komunitas Yustisia, 2(1).

Sant, G. A. N., Yuliartini, N. P. R., \& Mangku, D. G. S. (2020). Perlindungan Hukum Terhadap Korban Tindak Pidana Penyalahgunaan Narkotika di Kabupaten Buleleng. Jurnal Komunitas Yustisia, 2(3), 71-80.

Saputra, I. G. A., Yuliartini, N. P. R., SH, M., Mangku, D. G. S., \& SH, L. M. (2019). Perlindungan Hukum Terhadap Anak Sebagai Korban Tindak Pidana Pelecehan Seksual Di Kabupaten Buleleng. Jurnal Komunitas Yustisia, 2(1).

Soekanto, Soerjono dan Sri Mamudji, Penelitian Hukum Normatif: Suatu Tinjauan Singkat, (Jakarta: Raja Grafindo Persada, 2003), Hlm 12.

Undang-Undang No. 1 Tahun 2004 tentang Pembendaharaan Negara.

Undang-Undang No. 31 Tahun 1999 jo Undang-Undang Nomor 20 Tahun 2001.

Undang-Undang No. 8 Tahun 2010 tentang Tindak Pidana Pencucian Uang.

Yuliartini, N. P. R. (2019). Kenakalan Anakdalam Fenomena Balapan 
Liardi Kota Singaraja Dalam Kajian Kriminologi. Jurnal Advokasi, 9(1), 31-43.

Mangku, D. G. S. (2010). Pelanggaran terhadap Hak Kekebalan Diplomatik (Studi Kasus Penyadapan Kedutaan Besar Republik Indonesia (KBRI) di Yangon Myanmar berdasarkan Konvensi Wina 1961). Perspektif, 15(3).

Mangku, D. G. S. (2011). Peluang dan Tantangan ASEAN Dalam Penyelesaian Sengketa Kuil Preah Vihear Di Perbatasan Kamboja dan Thailand. Pandecta: Research Law Journal, 6(2).

Mangku, D. G. S. (2012). Suatu Kajian Umum tentang Penyelesaian Sengketa Internasional Termasuk di Dalam Tubuh ASEAN. Perspektif, 17(3). 